\title{
Difficult Women
}

\author{
Jennifer Henderson
}

Plastits, Shonagh Adelman's stunning image-text on the cover of this issue, taunts the onlooker with its invitation to map an intimate, beckoning first-person voice on to the woman proferring her breasts. But then the image disrupts this porn convention with folds of shiny plastic packaging that suggest the remoteness and inauthenticity of the woman. Either that, or the shiny folds of packaging actually heighten the appeal of the image, holding out the possibility of purchase and ownership, and it's the line of text - "I want you to check me out. Get to know me in my absence so that you'll learn everything you need to know about what I like" - that complicates the commodity appeal, with the demand that the onlooker imagine this sexual subject's pleasures. Critical feminist resignification and/or provocation of desire imagining desire, Adelman's image-text seems to me to be a perfect instance of the kind of feminist avant-garde sexual/textual violence vindicated by Dianne Chisholm as "affirmative in its erotic and poetic negation of naturalized barbarism, its provocative violation of sexist norms" (7).

Our call for texts ruminating on and instantiating the difference of a feminist avant-garde drew a number of texts which experiment with such affirmative violence. Nadine Ltaïf's "Shakespeariennes," for instance, is a poem in which love between two women "has no tenderness about it / on the contrary." The angry narrator of Allison Eir Jenks' "Man's Share of Woman," promises to mark "with deep bites." In Michèle Causse's "Court of Appeal," a lesbian offers dense, metaphorical replies to her interrogator's questions about a dead lover, and the suspicious demand for straight answers is frustrated by a "criminal" excessiveness. In an interview with Françoise Armengaud about the French writer of the 1950s, Violette Leduc, Causse denounces the publishing world which received Leduc's difficult, intrepid work in the manner of the deaf and suspicious interrogator, with a "barbaric" editorial practice that excised Thérèse et Isabelle from her Ravages, and erased her jubilant demystifications of the phallus. 
Along the lines of Nicole Brossard's pivotal declaration, "I have murdered the womb and I am writing it" (21), several contributors violate the most privileged instrument of mother-making, the fake baby. Diana Thorneycroft's photographs of scorched, decaying, mutilated dolls work their horror by literalizing the little girl's fantasy of a real, live doll - the photographs literalize this fantasy, however, by giving the dolls lost life. In Gloria Escomel's story, "Entre l'ange et la poupée," when a girl can no longer bring herself to perform mothering on a repulsive doll with a creepy blank gaze, she stages an "accident" in which her doll falls into the ocean. The tenuous distinction between a living and dead baby is the subject of the poem, "January 1993," which moves associatively between "carriage" and "miscarriage," "intricate home-made baptism dress" and coffin "covered with white material" and inserts, in the midst of this space of uncertainty, a woman voicing the opinion that abortion is cruel.

In her photo-installation, Annie Get Your Gun, Lynne Marsh invites women to strap on a symbol of virility and masculine power before the mirror, and records the sense of estrangement and the play with selfrepresentation that is permitted by an appropriation of the symbolic weight of the gun and its attendant language of gesture. Ingrid $\mathrm{Chu}$, too, insists on the allure of what she subjects to critical commentary, refusing the avant-garde impulses of destruction, negation and the clean break in her three-panelled installation, Hype (I Still Believe). Adopting one of the seductive poses of fashion advertising in each of these panels, Chu concretizes her desire to identify with such images, but also interrupts their transparency by running across each panel a screen of text that only becomes legible at close proximity as the word "hype" repeated again and again.

The costume-based performance art of Shawna Dempsey, as Lynda Hall's reading of Mary Medusa argues, stages the contradictions of patriarchal ideology and performs to excess misogynist ideas about women, using the body as text to play with ironic juxtapositions and visual metaphors centred on Medusa, a figure of female rage. Anne Blonstein's prose poems, "Perpetua's Visions," take their inspiration from texts by and about martyrs and mystics in their search for a language of pain: "sorrows roar their sultry vulnerability. then too smooth. unnameable sores cover differences. obscure laments scratch with the aid of punctuated abandonments. thereupon deeper. as soon as those few in a corner of courage stagger reason." Grace Kehler thinks about our "guilty" 
yearning for the perfect operatic voice, the implication of the desire for unearthliness in the mutilation of bodies, in her reading of Gérard Corbiau's film about the eighteenth-century castrato, Farinelli. In "Missing Body before the Law: bp Nichol's The Martyrology and the Poetics of Language Writing Revisited," Karlyn Koh probes an important text of the English-Canadian avant-garde for the reintroduction of a law of identity that requires a feminine and a primitive relegated to a presymbolic outside. Behind the hidden face on the cover of Book Six, she asks, does there lurk "an ' $\mathrm{I}$ ' in search for ' $\mathrm{i}$ '" $\mathrm{s}$ that are One, represented and seen as the abject and unassimilable"?

Anglo-American feminist critics of Julia Kristeva, pointing to her privileging of the dyad mother/male avant-garde writer and her theory of female "asymbolia," have accused Kristeva of silencing the woman writer. Miglena Nikolchina's discussion of Kristeva's work attempts to answer these criticisms by pursing the question, from what position is Kristeva herself able to speak? Remembering Kristeva's belief that the condition of foreignness to language is necessary if one is going to "take up the exhorbitant wager of carrying the rational project to the outer borders of the signifying venture of men," Nikolchina argues that Kristeva consistently risks the stable subject of theory in her work, coupling it with destabilized, precarious subjects like the melancholic. (Part II of Nikolchina's essay will appear in the next issue of Tessera.)

As a military metaphor, the "avant-garde" suggests the arrival of an advance army come to clear a space for the imminent invasion and installation of a new regime of power and truth. In an essay published elsewhere, Mary Wilson Carpenter has wondered about the relation between apocalyptic discourses (on the end of things as they are) and gendered violence "given not only the existence but the canonized status of the Book of Revelations in our Western, Christianized culture" (111). Is some version of the burning of the Whore at stake in all visions of apocalypse, of which the avant-garde invasion is arguably one instance? A number of contributions to this issue of Tessera explore themes of violence against women, and we include them in order to produce a tension between textual violence and violation. Janis Harper's "What Happened" represents the betrayal of the language of positivist evidence which cannot account for a woman's shattering loss of security and autonomy in a threatened sexual attack. Mary Nyquist's two poems touch on the contrary necessities of amnesia and over-reading in a world of daily violences: the bruise is a frustrating, unyielding text for one of 
her narrators, a woman alienated from her body, whereas Nyquist's other narrator is an expert reader of the gestural language of impending threat in men. Louise Bak's poem, "Reality Scare," borrows language from Star Trek, vampire legend, and parasitology to renew our perception of medical invasion and wards off pathos by imagining her womanin-a-coma as an avenging monster: "you pull the tube from your throat/bluish eyelids lift like onion poultices."

In Patricia Seaman's story, the narrator also suffers the medicalization of her body in a paternalistic hospital environment that leaves her with a profound sense of vulnerability. As the narrator remembers how she learned early on to distrust the "words in circulation" and to hold in reserve her most precious thoughts, she discovers an emblem for a wily existence in the gaps of the symbolic order: "when I was a little girl with my eyes screwed up against the glare of the sun and my sock fallen around my ankle, I was as stingy as a rich old man." As "stingy," too, as the lesbian in Causse's scene of interrogation, where "being difficult" is both a mode of conduct and a use of language: intransigent and opaque, resistant and elliptical. Fiona Smyth's paintings and ink drawings telescope these two senses of "difficulty" as well, in a groundless space of floating subconscious imagery and religious and popular culture iconography. In this landscape of metamorphosis, female figures sprout phalluses, troll dolls come to life, and girls are invested with an uncanny sexual power.

\section{Work Cited}

Brossard, Nicole. These Our Mothers or: The Disintegrating Chapter. Trans. Barbara Godard (Toronto: Coach House Press, 1983). Carpenter, Mary Wilson. "Representing Apocalypse: Sexual Politics and the Violence of Revelation" in Postmodern Apocalypse: Theory and Cultural Practice at the End, ed. Richard Dellamora (Philadelphia: U of Pennsylvania P, 1995): 107-35.

Chisholm, Dianne. "Avant-Garde Sexualities: Eroticism in an Age of Barbarism." English Studies in Canada, 19.1 (March 1993): 5-22. 